University of Nebraska - Lincoln

DigitalCommons@University of Nebraska - Lincoln

\title{
Physical mapping of the bovine, caprine and ovine homologues of the paired box gene PAX8
}

\author{
N. L. Lòpez-Corrales \\ Roslin Institute (Edinburgh) \\ T. S. Sonstegard \\ USDA-ARS \\ T. P. L. Smith \\ USDA-ARS, tim.smith@ars.usda.gov
}

Follow this and additional works at: https://digitalcommons.unl.edu/usdaarsfacpub

Part of the Agricultural Science Commons

Lòpez-Corrales, N. L.; Sonstegard, T. S.; and Smith, T. P. L., "Physical mapping of the bovine, caprine and ovine homologues of the paired box gene PAX8" (1999). Publications from USDA-ARS / UNL Faculty. 792. https://digitalcommons.unl.edu/usdaarsfacpub/792

This Article is brought to you for free and open access by the U.S. Department of Agriculture: Agricultural Research Service, Lincoln, Nebraska at DigitalCommons@University of Nebraska - Lincoln. It has been accepted for inclusion in Publications from USDA-ARS / UNL Faculty by an authorized administrator of DigitalCommons@University of Nebraska - Lincoln. 


\title{
Physical mapping of the bovine, caprine and ovine homologues of the paired box gene PAX8
}

\author{
N.L. Lòpez-Corrales, ${ }^{a}$ T.S. Sonstegard ${ }^{b}$ and T.P.L. Smith ${ }^{c}$ \\ ${ }^{a}$ Roslin Institute (Edinburgh), Roslin, Midlothian (UK); \\ b USDA-ARS Beltsville Agricultural Research Center, Beltsville MD; \\ c USDA-ARS U.S. Meat Animal Research Center, Clay Center NE (USA)
}

\begin{abstract}
The PAX8 gene, a member of the human paired box gene family, was mapped by FISH to chromosome 11 in cattle and goat and to the short arm of chromosome 3 in sheep. The cytogenetic position of PAX8 on BTA 11 and on its homologue OAR $3 p$ lies in the region where the interleukin beta (IL1B) gene has been previously located, (BTA $11 \mathrm{q} 22.1 \rightarrow \mathrm{q} 22.3$ and OAR $3 \mathrm{p} 25 \rightarrow \mathrm{q} 26$ respectively; LòpezCorrales et al., 1998). The results indicated that PAX8 as well
\end{abstract}

as interleukin beta and interleukin alpha (IL1B and IL1A) genes detected on the human chromosome segment HSA $2 \mathrm{q} 13 \rightarrow \mathrm{q} 21$ maintain a similar order and location in these three related species. In addition, the breakpoint in conserved synteny can now be narrowed to a position between the protein $\mathrm{C}$ (PROC) and PAX8 genes, which lie in close proximity on HSA 2.
PAX8 is a member of a family of human paired box genes. The nine known human paired box genes encode transcription factors that are thought to play a fundamental role in early embryonic development. Some of the PAX genes are oncogenes, at least six human phenotypes are caused by loss-of-function mutations in three different PAX genes, Waardenburg syndrome (WS), and kidney and retinal defects (PAX3, PAX6 and PAX2 respectively; Read, 1995). In mice Pax 8 encodes a sequence-specific transcription factor expressed in the developing secretory system and in both developing and adult thyroid (Poolev et al., 1992). Recently Dehbi and Pelletier (1997) provided evidence that PAX8 may function to induce the tumour supressor gene WT1, which is involved in the development of Wilms tumors (WTs) and plays a role in normal urogenital development (Pelletier et al., 1991). PAX8 has been located in humans in the distal part of chromosome 2, specifically HSA 2 q12 $\rightarrow$ q14. (Poolev et al., 1992, Stapleton et al., 1993). Comparative mapping of humans, cattle and sheep has shown a significant conservation of synteny between HSA $2 q$ and bovine and ovine chromosome 2 (BTA 2 and OAR 2q). However, the gene order within this overall synteny has been significantly

Received 18 November 1998; revision accepted 5 February 1999.

Request reprints from T.P.L. Smith, USDA-ARS U.S. Meat Animal Research Center, PO Box 166, Clay Center NE 68933 (USA); telephone: (402) 762-4369; fax: (402) 762-4390; e-mail: smith@email.marc.usda.gov altered. In fact four small conserved segments resulting from two major rearrangements involving COL3AI and INHBB have been reported (Sonstegard et al., 1997). In addition to these rearrangements, a breakpoint in the conservation of synteny has been identified in the vicinity of the centromeres. Accordingly, PROC, IL1B, IL1R1 and IL1R2 (interleukin receptors I and II) lie near the HSA 2 centromere (HSA 2q13 $\rightarrow$ q21), while their bovine counterparts lie on BTA 2 (PROC) or BTA 11 (ILR1, IL1B; Yoo et al., 1994; Sonstegard et al., 1997). These findings have been extended to sheep and goat (LòpezCorrales et al., 1998). PAX8 has been located on a human YAC contig containing the IL1A and IL1B genes, lying slightly telomeric between IL1B and PROC (Spurr et al., 1996). Therefore it was not possible to predict whether PAX8 is located on BTA 2 or BTA 11 , and similarly on OAR 2 q or OAR $3 p$. We report the determination of the cytogenetic location of PAX8 in three bovid species to further refine the comparative map in this region and narrow the position of the evolutionary breakpoint.

\section{Materials and methods}

Isolation and analysis of genomic probes for FISH

The isolation of the PAX8 cosmid has been described (Sonstegard et al., 1998) which used an iterative screening process and primers designed from the human PAX8 cDNA sequence (GenBank accession X69699). The primer sequences used to obtain the cosmid clone for PAX8 were: TTGGCAGGTACTACGAGACTGGCAAACATGGTAGGGTTCTG. DNA was isolated

\begin{tabular}{lll}
\hline KARGER & $\begin{array}{l}\text { E-mail karger@karger.ch } \\
\text { Fax +41 61306 12 34 } \\
\text { http://www. karger.com }\end{array}$ & (c) 1997 S. Karger AG, Basel \\
$0301-0171 / 99 / 0844-0179 \$ 17.50 / 0$
\end{tabular}

Accessible online at:

http://BioMedNet.com/karger 

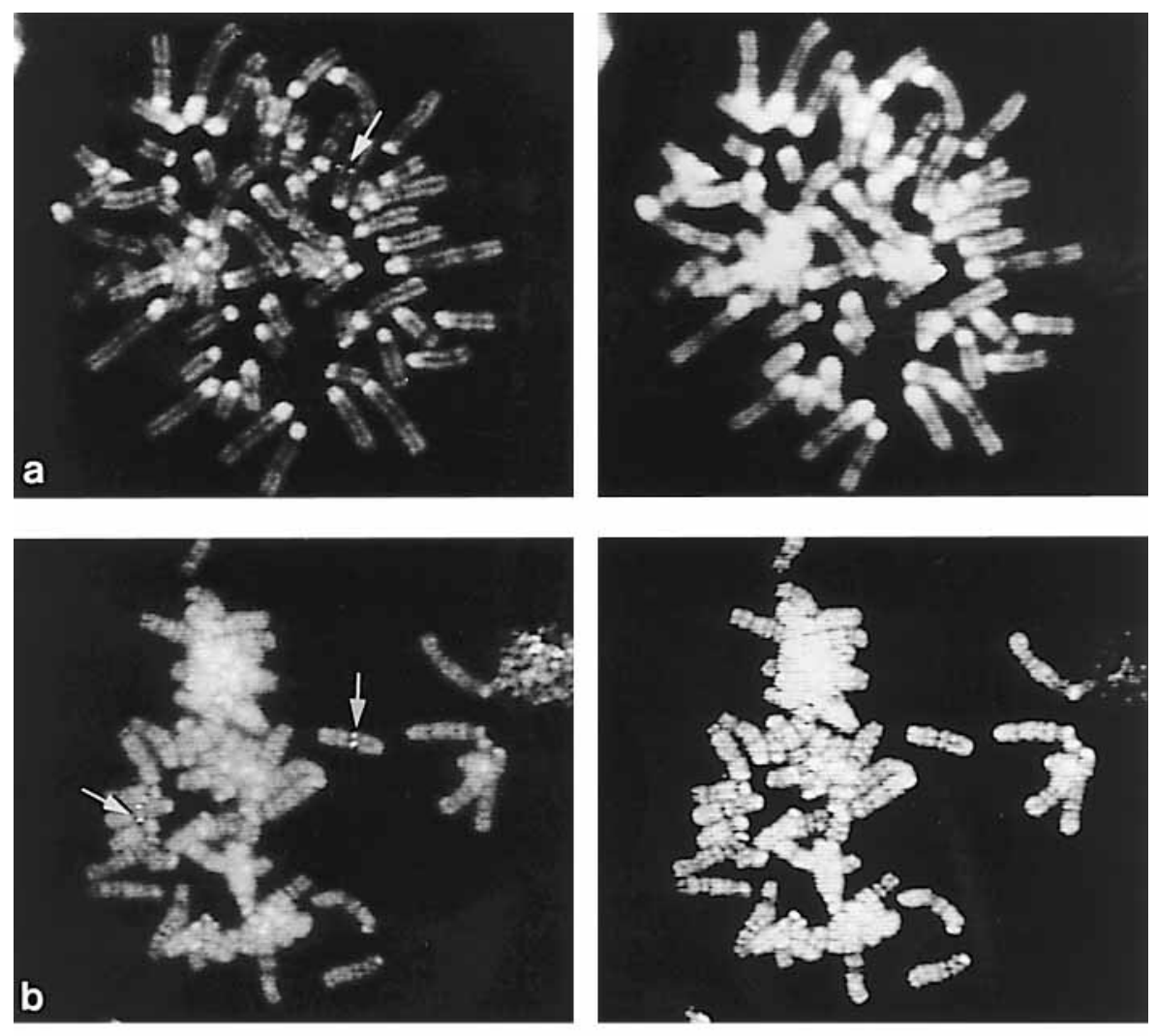

Fig. 1. Chromosomal localization of PAX8 by FISH. (Right) Biotinylated DNA of the cosmid clone containing the PAX8 gene was hybridized to metaphase chromosome spreads and the corresponding signals were detected with FITC on propidium iodide counterstained chromosomes showing the R-banding pattern. (Left) hybridization pattern of PAX8 in cattle (a), goat (b), and sheep (c) chromosomes showing a conserved location for the gene.
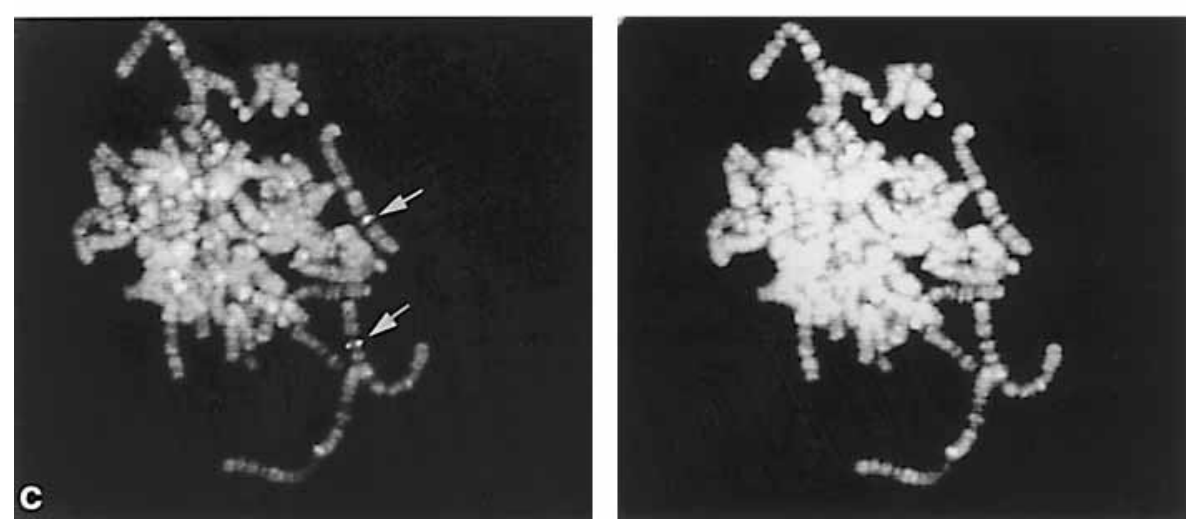

by ion exchange columns according to the manufacturer's protocol (Qiagen).

Chromosome preparation and FISH analysis

Probes were labeled with biotin by nick translation using a BioNick kit (Gibco) and purified with commercial Sephadex columns (5prime-3prime, Boulder (O). FISH analysis was according to the original method of Lichter et al. (1990) and Ponce de Leon et al. (1996). Chromosome spreads were obtained from peripheral whole blood cell cultures and R-banding of metaphase preparations were obtained according to Lemieux et al. (1992)

Digital imaging and probe localization

Digital images were obtained using a Zeiss Axioscope epifluorescence microscope coupled to a cooled CCD Camera. Fluorescein isothiocyanate (FITC) and propidium iodide (PI) signals were detected with BP 450-490 filter (Zeiss), recorded and photographed from the display monitor. Hybridization signals were assigned to specific bands according to the standard sheep and cattle R-banding pattern (ISCNDA 1989; Iannuzzi et al., 1995; Di Berardino and Iannuzzi, 1989).

\section{Results and discussion}

The presence of the target genes in the cosmid clones was detected by sequence analysis and PCR with other exon-specific primers. Cosmid probes were first hybridized to cattle chromosome spreads and revealed signals in the BTA $11 \mathrm{q} 22.1 \rightarrow \mathrm{q} 22.3$ region (Fig. 1a). The same probe and conditions were then used to perform FISH on sheep and goat chromosomes. The signals were detected at OAR $3 \mathrm{p} 26 \rightarrow \mathrm{p} 25$ and on goat chromosome 11 , (CHI 11q22.1 $\rightarrow$ q22.3), and cattle (BTA 11, Figs. 1b and 1c, respectively). PAX8 is located in a narrow region to which IL1B (human interleukin beta), IL1A (interleukin alpha) and its receptor IL1R1 have also been mapped in cattle and sheep (O'Brien et al., 1993; Lòpez-Corrales et al., 1998). This area is part of a segment of HSA 2q (segment IV in Sonstegard et al., 1997), which has been rearranged on BTA 11 (Smith et al., 1997; Lòpez- 


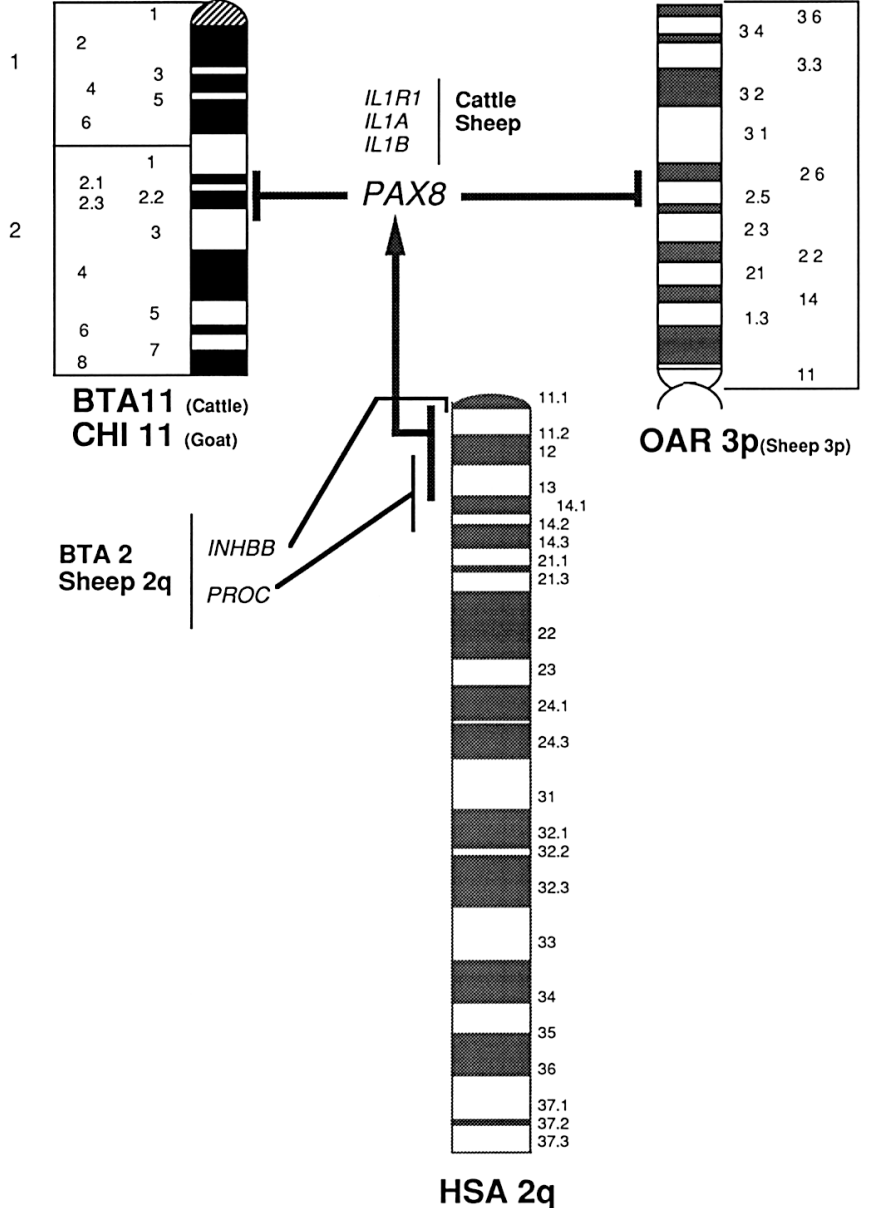

Corrales et al., 1998). The comparison of PAX8 location in human, cattle, sheep and goat is presented in Fig. 2.

The cytogenetic positioning of PAX8 reported here demonstrates that the change in synteny which occurred relative to HSA 2 q12 $\rightarrow$ q14.3 has been conserved in the three bovid species examined. This result suggests that the evolutionary events leading to the observed differences must have occurred either in the primate lineage after the split with bovids, or in the bovid lineage after the split with primates but prior to speciation of the three livestock species. The shuffling of gene order seen between HSA $2 q$ and BTA 2 is also observed on BTA 11 , since PAX8 and IL1R1 lie in close proximity on HSA 2q, but are $51.7 \mathrm{cM}$ apart on BTA 11 (66 and $14.3 \mathrm{cM}$ respectively) (USDA-ARS, MARC Cattle Linkage Map, http.//www.niarc. usda.gov). The results reported here add more information to support the idea that most bovid species share similar patterns of synteny, which permits the use of data from the more developed cattle and sheep maps to be applied in goat.

\section{Acknowledgements}

We wish to thank Drs A. Archibald and S. Anderson from the Roslin Institute, Roslin, Scotland, for helpful discussion and advice.

Fig. 2. Human chromosome $2 \mathrm{q}$ compared with the three species in this study The chromosome rearrangement involving the human PAX8, ILIRI, ILIA and ILIB genes is indicated. The relative location of these genes has been rearranged without modification in cattle and sheep. In addition the INHBB and PROC flanking genes also maintain a similar position in human, cattle and sheep.

\section{References}

Dehbi M, Pelletier J: PAX8-mediated activation of the WT1 tumor supressor gene. EMBO J 15:42974306 (1996).

Di Berardino D, Iannuzzi L: Detailed description of Rbanded bovine chromosomes. J Hered 73:434-438 (1989).

Iannuzzl L, Pia Di Meo G: Chromosomal evolution in bovids: a comparison of cattle, sheep and goat Gand R-banded chromosomes and cytogenetic divergences among cattle, goat and river buffalo sex chromosomes. Chrom Res 3:291-299 (1995).

ISCNDA (1989): International system for cytogenetic nomenclature of domestic animals, Di Berardino D, Hayes H, Fries R, Long S (eds). Cytogenet Cell Genet 53:65-79 (1990).

Lemieux N, Dutrillaux B, Viegas-Péquignot E: A simple method for simultaneous R- or G-banding and fluorescence in situ hybridization of small singlecopy genes. Cytogenet Cell Genet 59:311-312 (1992).

Litcher P, Tang CC, Call K, Hermanson G, Evans GA, Housman D, Ward DC: High resolution mapping of human chromosome 11 by in situ hybridization with cosmid clones. Science 237:64-69 (1990).
Lòpez-Corrales NL, Sonstegard TS, TPL Smith: Comparative mapping: cytogenetic location of PROC, EN1, ALP1, TNP1 and IL1B genes in cattle and sheep reveals a conserved rearrangement relative to the human genome. Cytogenet Cell Genet 83:35-38 (1998).

O'Brien SJ, Womack LE, Lyons MA, Moore KJ, Jenkins NA, Copeland NG: Anchored reference loci for comparative genome mapping in mammals. Nature Genet 3:103-112 (1993)

Pelletier J, Schalling M, Buckler AJ, Rogers A, Haber DA, Housman D: Expression of the Wilms tumor gene WT1 in the murine urogenital system. Genes Dev 5:1345-1356 (1991).

Ponce De Leon A, Ambady A, Hawkins GA, Kappes SM, Bishop MD, Robl JM, Beattie CW: Development of a bovine $\mathrm{W}$ chromosome linkage group and painting probes to asses cattle, sheep and goat $\mathrm{X}$ chromosome segment homologies. Proc natl Acad Sci, USA 93:3450-3454 (1996).

Poolev A, Fickenscher H, Mundlos S, Winterpacht A, Zabel B, Fidle A, Gruss P, Plachov D: PAX8, a human paired box gene: isolation and expression in developing thyroid, kidney and Wilms tumors. Development 116:611-623 (1992).

Read AP: Pax Genes-Paired feet in three camps. Nature Genet 9:333-334 (1995).

Smith TPL, Lòpez-Corrales NL, Kappes SM, Sonstegard TS: Myostatin maps the interval containing the bovine mh locus. Mammal Genome 8:742-744 (1997).
Sonstegard TS, Lòpez-Corrales NL, Kappes SM, Beattie CW, Smith TPL: Comparative mapping of bovine and human chromosome 2 identifies segments of conserved synteny containing the bovine mh locus. Mammal Genome 8:750-754 (1997).

Sonstegard TS, Kappes SM, Keele JW, Smith TPL: Refinement of bovine chromosome 2 linkage map near the mh locus reveals complex rearrangement between the bovine and human genomes. Anim Genet (In press 1998).

Spurr NK, Bashir R, Bushby K, Cox A, Cox S, Hildebrandt F, Hill N, Kao FT, Krols L, Marzella R, Miller N, Nothwang HG, Rocchi M, Sarfarazi M, Stratakis CA, Wallgren-Petterson C, Naylor S: Report and abstracts of the Fourth International Workshop on Human Chromosome 2 Mapping 1996 Cytogenet Cell Genet 73:255-273 (1996).

Stapleton P, Weith A; Urbanek P, Kozmik Z, Busslinger M: Chromosomal location of seven PAX genes and cloning of a novel family member. Nature Genet 3:292-298 (1993).

Yoo J, Stone RT, Kappes SM, Beattie CW: Linkage analysis of bovine interleukin receptor types I and II (IL1R I, II). Mammal Genome 5:820-821 (1994). 